Goswin Baumhögger with Ulf Engel and Telse Diederichsen

\title{
The Struggle for Independence
}

Documents on the Recent Development of Zimbabwe (1975-1980), Vols I-VII, Institut für Afrika-Kunde, Hamburg 1984, ISBN 3-922887-37-6.

According to Erich Kästner, the majority of all new books are copied from old books. Tracking down primary sources takes time and effort - and is seldom honoured by the academic industry. Nevertheless, anyone prepared to do this for the last phase of Rhodesia's transition to Zimbabwe (1975-1980) will now find the way considerably smoothed. Goswin Baumhögger and his assistants, Telse Diederichsen und Ulf Engel, have painstakingly collected a wealth of material that is unparalleled - and not only for Zimbabwe. The collection is presented in seven volumes of small print covering 1500 pages. The material is divided chronologically into 27 chapters, from 'Main Events 1975: A Brief Overview' (Chapter 1) to 'Approaching Independence', March - April 1980 (Chapter 26). Chapter 27 generously includes 'The Constitution of Zimbabwe'.

The material is drawn from three different sources:

1. 'Primary' sources make up approx. $60 \%$ of the total text. The 1060 original documents, many reproduced in full, range from UN documents to broadcasts from Radio Salisbury.

2. 'Secondary' sources comprise approx. 1500 items: articles from - for the most part African - daily and Sunday newspapers and transcripts of radio broadcasts.

3. Finally, there are about 500 newspaper editorials and 170 radio commentaries.

It will be evident from the foregoing that the work is neither a documentation in the conventional sense nor simply a compilation of newspaper clippings. Secondary sources serve primarily to plug gaps in written primary sources.

Of course, the choice and presentation of materral is always open to quibbles. Thus, one might have wished for a more extensive documentation of the military aspect of decolonization. But, as the editors point out, little written material on the guerrilla struggle and the counter-insurgency strategy of the Smith government was made available at the time and relatively little has been published since then.

Apart from this, the comprehensiveness of the material speaks for itself. I have tried in vain to find other gaps. A particular quality of the volumes in the mass of information gathered from widely scattered and often virtually inaccessible African sources - especially from the liberation movements. Everything is documented in detail and wherever possible has been checked and counterchecked, a reflection of Baumhögger's training as an historian.

All in all this collection is an astonishing achievement. One can only hope that the work will be appropriately honoured - if only, and especially, as an inexhaustible quarry for future generations of German students of Zimbabwe in particular and African affairs in general. In Zimbabwe, at any rate, this documentation is already available not only - as 
one might expect - in the appropriate research institutes and the university but also in some secondary schools.

You, happy Africa, are more fortunate in some ways.

Gerald Braun

\section{Ludwig Gruber \\ Landwirtschaftliche Kooperation der Europäischen Gemeinschaft mit Entwicklungslän- dern am Beispiel der Lomé-Verträge \\ herausgegeben von der Stiftung Wissenschaft und Politik, Ebenhausen 1987, 223 S.}

Der Beitrag, den die zwischen der EWG und ihren Mitgliedstaaten sowie nunmehr 66 Entwicklungsländern aus Afrika, Karibik und Pazifik (AKP-Staaten) in den Jahren 1975, 1979 und 1984 geschlossenen, sog. Lomé-Abkommen vor dem Hintergrund einer vielpropagierten Neuen Weltwirtschaftsordnung und für die Herausbildung eines genuin partnerschaftlich strukturierten Entwicklungsvölkerrechtes geleistet haben, ist bereits in einer Vielzahl wissenschaftlicher Veröffentlichungen diskutiert worden. Die Frage, ob und inwiefern sie zu einer Behebung der wirtschaftlichen und sozialen Entwicklungsunterschiede zwischen EWG- und AKP-Staaten geführt haben, wurde dabei meist global beantwortet.

Hingegen konzentriert sich Gruber in seiner Untersuchung - der stark gekürzten Fassung einer 1985 von der Universität München angenommenen politikwissenschaftlichen Magisterarbeit - auf die landwirtschaftliche Kooperation, wobei er diese auf den Agrarhandel zwischen AKP und EWG, das System zur Stabilisierung der landwirtschaftlichen Exporterlöse (STABEX) und die agrarische Projektkooperation beschränkt. Die in diesen drei Teilbereichen gewonnenen Ergebnisse werden in einem vierten Abschnitt anhand des Fallbeispiels Elfenbeinküste überprüft.

Methodisch auf diverse, aus - theoretisch recht knapp begründeten - integrationistischen bzw. dissoziationistischen Denkansätzen abgeleitete Kriterien zurückgreifend, geht Gruber über die üblichen makroökonomischen und interstaatlichen Analysen hinaus und bezieht intrastaatliche, an den sozioökonomischen Strukturen der AKP-Staaten orientierte Fragestellungen mit ein, indem er auch - allerdings mit unterschiedlichem Gewicht - untersucht, welche sozialen Gruppen oder Institutionen Nutznießer des Agrarhandels mit der EWG geworden sind.

Anhand ausführlichen statistischen Materials weist Gruber für den Zeitraum von 1975-1982 nach, daß die in den Lomé-Abkommen festgelegte bevorzugte Behandlung der AKP-Staaten, deren Agrarprodukte zwar zu weit über $90 \%$ zollfreien Zugang zum EG-Markt haben, die ihrerseits aber lediglich an das Diskriminierungsverbot und Meistbegünstigungsgebot gebunden sind, nicht zu einer entwicklungsorientierten Veränderung 